\title{
No lack of regulatory B cells in patients with Multiple Sclerosis
}

\author{
Laure Michel ${ }^{1,2,3^{*}}$, Mélanie Chesneau ${ }^{1,3}$, Philippe Manceau ${ }^{1}$, Alexandra Garcia ${ }^{1,3}$, Marion Salou ${ }^{1,3}$, \\ Annie Elong Ngono 1,3, Annaïck Pallier ${ }^{1,3}$, Marylène Jacq-Foucher ${ }^{2}$, Fabienne Lefrère ${ }^{2}$, Sandrine Wiertlewski ${ }^{2}$, \\ Jean-Paul Soulillou ${ }^{1,3}$, Nicolas Degauque ${ }^{1,3}$, David-Axel Laplaud ${ }^{1,2,3 \dagger}$, Sophie Brouard ${ }^{1,3+}$
}

From 7th European Workshop on Immune-Mediated Inflammatory Diseases

Noordwijk aan Zee, the Netherlands. 28-30 November 2012

\section{Background}

Recent data support a prominent role for B cells in MS physiopathology. Recently it has emerged that subsets of B cells secreting IL-10 negatively regulate disease symptoms in Experimental Autoimmune Encephalomyelitis (EAE). However, the involvement of such regulatory B cells in MS remains unclear.

\section{Aim}

We aimed to study the frequency, phenotype and function of regulatory B cells in MS patients as compared to Healthy Volunteers (HV).

\section{Methods}

Sixty-three untreated MS patients and $58 \mathrm{HV}$ were included in this study. IL-10 secretion by B cells and phenotype of $\mathrm{IL}-10^{+} \mathrm{B}$ cells were studied after $5 \mathrm{~h}$ (B10 cells) and $48 \mathrm{~h}$ of stimulation (B10pro cells) by CD40L and ODN. Coculture assays with prestimulated B cells and responding $\mathrm{CD} 4^{+} \mathrm{CD} 25^{-} \mathrm{T}$ cells were performed for 3 days.

\section{Results}

No significant difference was found either for IL-10 secretion ability of B cells after $5 \mathrm{~h}$ or $48 \mathrm{~h}$ of stimulation. The analysis of B10pro cells phenotype revealed mainly a memory phenotype in MS and HV, even if both naïve and immature subsets were also able to secrete IL-10. Prestimulated $\mathrm{B}$ cells from MS inhibited $\mathrm{CD} 4^{+} \mathrm{CD} 25^{-} \mathrm{T}$ cell proliferation in the same manner than HV by a contact dependent mechanism, independently of IL-10 and TGF- $\beta$ secretion.

† Contributed equally

${ }^{1}$ INSERM, UMR 1064, Nantes, France

Full list of author information is available at the end of the article

\section{Conclusion}

Altogether, our data show that regulatory B cells have a conserved frequency, phenotype and function in the blood of patients with MS suggesting that B cells do not contribute to the physiopathology of the disease.

\section{Acknowledgements}

This work was funded by ARSEP.

\section{Author details}

'INSERM, UMR 1064, Nantes, France. ${ }^{2}$ CHU Nord Laennec, Service de Neurologie, Nantes, France. ${ }^{3} \mathrm{CHU}$ de Nantes, ITUN, Nantes, France.

Published: 28 November 2012

\section{doi:10.1186/1479-5876-10-S3-04}

Cite this article as: Michel et al:: No lack of regulatory B cells in patients with Multiple Sclerosis. Journal of Translational Medicine 2012 10(Suppl 3): O4.
Submit your next manuscript to BioMed Central and take full advantage of:

- Convenient online submission

- Thorough peer review

- No space constraints or color figure charges

- Immediate publication on acceptance

- Inclusion in PubMed, CAS, Scopus and Google Scholar

- Research which is freely available for redistribution
C Biomed Central

\section{() Biomed Central}

